\title{
Internationalization Experience of Chinese Ancient Currency and Its Enlightenment
}

\author{
Dechen Ding *
}

\author{
Associate Professor \\ School of Insurance \\ Shandong University of Finance and Economics \\ Jinan 250014, China \\ Email:dechend@163.com
}

\begin{abstract}
Based on historical documents and archaeological excavations, this paper first comprehensively introduces the historical evolution of cross-border circulation of ancient Chinese currency, then deeply analyzes the historical status of ancient Chinese currency in the world currency, and finally puts forward some inspirations for the current internationalization of RMB.
\end{abstract}

Keywords: Chinese ancient currency, Global circulation, Enlightenment, RMB internationalization

\section{INTRODUCTION}

As an ancient civilization in the world, China has a brilliant culture and a currency culture, which constitutes one of China's cultures. It has a long history, rich and colorful, and far-reaching influence. It is highly praised by the academic circle of international monetary history and honored as the representative of eastern monetary culture ${ }^{[1]}$. Chinese copper coins have played an important role in international currency in ancient and modern Southeast Asia, as well as in the Indian Ocean, Africa and the Near East. It is still in some countries and ethnic areas, cherished by people as a mascot and preserved.

\section{THE HISTORY OF CROSS-BORDER CURRENCY CIRCULATION IN ANCIENT CHINA}

\subsection{The origin of cross-border currency circulation in ancient China}

In $221 \mathrm{BC}$, the first Emperor of Qin unified the country and unified the currency system in the same year, with the gold as the upper coin, the yi as the unit and the two halves of the coin as the lower one. From then on, the basic form of the Chinese coin, which was round outside and square inside, was determined and continued for more than 2,000 years. The unification of the country and the currency system has laid a solid foundation for the cross-border circulation of currency.

The cross-border circulation of Chinese currency originated from the carrying of envoys, that is, the foreign exchanges of the country. As a general equivalent, Chinese copper coins have been flowing out of China since the Han Dynasty, but the amount is small and the influence is not significant. The form of circulation is mainly carried by envoys and gifts. According to the book of Han, when Zhang Qian was sent to the Western Regions in $139 \mathrm{BC}$ at the command of Emperor han wu of the Han Dynasty, he carried a large number of Chinese coins abroad, which is the earliest record of the cross-border flow of Chinese money in historical books.

\subsection{The amount of money circulating across borders in ancient China}

Chinese coins were mainly circulated across the border in three aspects, namely, "return grant" by ambassadors, trade and private transport by merchants. Since the Tang Dynasty, Chinese copper coins began to circulate abroad. The international circulation of a currency is not accidental, but depends on the state of the country's political and economic power. Since the Tang and Song Dynasties, Chinese copper coins, as a means of international payment, have become the common currency of many Southeast Asian countries 
and regions, leading to the "money shortage" in the Tang and Song Dynasties, that is, the domestic circulation of copper coins is seriously insufficient. The government was forced to adopt "silk and money", which meant that silk was used instead of money to enter the circulation. The Song government attached importance to the problem of money shortage, vigorously drum copper coins. According to records, the production of copper coins cast in the Song Dynasty was more than 19 times that in the Tang Dynasty.

Although great efforts were made to drum copper coins in the Song Dynasty, they still could not meet the demand of the domestic market, and the money shortage still existed and became more serious ${ }^{[2]}$. For example, copper wares were daily necessities for the people, but the Song Dynasty was very strict with copper. People could make 2 to 5 times of profits by selling and casting copper coins. Some people made statues of Buddha and sacrificial offerings, while in the southern minority areas, bronze drums were made, which made copper coins withdraw from circulation. There are private copper money usury, and aggravate the shortage of money. Therefore, the Song government ordered that no more than five thousand copper coins should be kept in private, and the violators were fined heavily. A more important reason is the outflow of copper coins. In the northern part of the Song Dynasty, all the money in the Liao and Xia markets was the copper coins of the Song Dynasty. They traded furs and other special products for copper coins, while in the southern part of the Song Dynasty, foreign merchants bought the coins through coastal ports.

There was a close trade relationship between the Song Dynasty and Arabia, and many Arabs did business in Guangzhou, Quanzhou and other coastal cities. The commercial traffic routes to Arabia in the Song Dynasty were called "the Road of Ceramics" and "the Road of fragrant medicine" ${ }^{[3]}$. It can be inferred from the fact that a large number of Chinese coins have been unearthed in modern archaeology in this area that Chinese coins were widely circulated in this area.

During the period of Yuan and Ming Dynasty, the government generally adopts an active opening up policy. The government organized a huge fleet of ships and carried out diplomatic activities and trade to the Southeast Asian countries for many times, so as to contact the sovereigns and strive for the initiative of maritime trade. Thus Zheng He and Wang Jinghong led their fleets to the Western Seas for seven times. All the goods shipped by Chinese ships to various countries were special Chinese products such as brocade qi, gauze, silk damask, blue and white porcelain, underglaze red porcelain, musk, rhubarb, cinnamon, iron wares, copper wares and refined handicrafts. At the same time, gold, silver and copper coins also flowed out in large quantities, which became an unavoidable fact.

\subsection{The influence of ancient Chinese currency on Southeast Asian countries}

Since modern times, a large number of Chinese copper coins, especially in the Song dynasty, have been unearthed in East and Southeast Asia, such as Japan and Indonesia. A large number of copper coins unearthed overseas help us to have a better understanding of the problem of "money shortage" in Tang and Song Dynasties. Chinese copper coins, especially those in Song Dynasty, may have played the role of international currency in history, but this understanding still needs further study. Chinese copper coins have been used for a long time in some areas and have continued to be used in modern times, such as in Bali, Indonesia, and recent archaeological finds have even found large amounts of Song Dynasty copper coins hidden under the beaches of Australia. The monetary system used by neighboring countries is relatively complex, such as Cambodia, Laos and Thailand in the Indo-China Peninsula. As the meeting point of Chinese and Indian cultures, they are bound to be influenced by the currency culture of two ancient civilizations. In addition, the peoples of the islands in the Pacific and Indian Oceans are also influenced by the culture of Islam. Some regional ethnic groups are good at creative development by integrating various monetary cultures, while the development of monetary commodity economy is in line with the political forces in different periods in history ${ }^{[4]}$.

In the early 19th century, a large amount of Mexican silver flowed into China, commonly known as "Eagle ocean". It is estimated that at least 500 million Mexican silver flowed into China. Although China has been influenced by the western monetary culture in modern times, in the long history, the distinctive Chinese monetary culture has always developed independently, and the light of Chinese monetary culture has always shone on Southeast Asia.

\section{THE HISTORICAL STATUS OF CHINESE ANCIENT CURRENCY IN THE WORLD CURRENCY HISTORY}

The currency culture of China has a history of more than 5,000 years. During the 10th and 15th centuries, the eastern monetary culture system with the Chinese monetary culture as the main body was formed in the world. The establishment of the independent monetary system in the East was actually the system with the Chinese monetary culture as the main body. A review of the development of maritime Silk Roads in various dynasties in China reveals that China's currency plays an important role in maritime trade exchanges with neighboring countries ${ }^{[4-6]}$.

First, to meet the needs of political and cultural exchanges. In ancient times, in order to show its power as a great country, China's feudal central dynasty 
adopted a soft policy towards some small countries around it, not hesitate to give them a large number of silk, tea, money and other goods, so that they could worship, and came to pay tribute one after another.

During the Reign of Yuan Shizu, the Yuan government once sent thousands of ships, carrying a large amount of food, gold and silver and other goods to reward the State of Java. When Zheng He went to the Western Seas in the Ming Dynasty, he also brought with him a large amount of Chinese silk, porcelain, coins and so on. Here, money is used as a gift to serve the purpose of the ruler, which is the primary role of money, while as a cultural exchange is secondary and has no economic role. In the history of China, such incidents happened quite frequently.

Second, as an intermediary of maritime trade. In the ancient maritime Silk Road trade, with the increasing development of trade, Chinese money, as a medium of Commodity Exchange, played a very important role, and even played the role of international currency. This is to restore the true nature of money. In history, in addition to barter, most of the mutual trade and folk trade between countries took money as the medium of exchange.

Third, Chinese copper coins are sold abroad as special commodities and then serve as international currency. From the Han dynasty to the Tang Dynasty, the currency exchange between China and other countries did not play an economic role. However, in the Song and Yuan Dynasties, fundamental changes took place and the ban on the export of copper coins in the previous dynasties was changed. During the reign of Emperor Shenzong in the early Northern Song Dynasty, the government allowed copper coins to be exported as a commodity. As a result, Chinese coins were continuously exported to other countries along with the increasingly prosperous trade. And some East and Southeast Asian countries such as Japan, Vietnam, Korea, Laos, Myanmar, Cambodia, due to their own little money, or their own currency system disorder, poor quality of money, are using or happy to use Chinese coins.

According to the Records of China and India, China's copper cash outflows to Japan and Southeast Asia country, and has been diffusing to the Persian gulf region, even in the middle of the east coast of Africa and the coast of Australia. This can be made of the unearthed real. Chinese coins have been unearthed in central Africa, Mesopotamia, countries in the Persian Gulf region and Mexico in Central and South America. Chinese ancient money, because of its fine production, acted as an international currency ${ }^{[7]}$.

By the Yuan Dynasty, China's international currency status was further improved, and the Yuan currency at that time actually became the international major currency, just like the British pound and the US dollar later. At that time, the yuan dynasty established the most advanced pure paper money system ${ }^{[5,8]}$. The Yuan Dynasty was the first country in the world to implement the pure paper currency system. Precious metals, gold, silver and copper coins were not allowed to circulate. Instead, the paper currency was strongly promoted by the state. It is a non-convertible note with unlimited legal capacity. It was accompanied by relatively perfect management measures. The centralized gold and silver, the prohibition of metal currency, the prohibition of gold and silver export, the special domestic bank notes, the setting of reserve funds for the issue of bank notes, the stabilization of bank note prices, the control of prices and other policies and measures in the modern bank note policies had taken form in the banknote law of the Yuan Dynasty. We cannot negate the originality and progress of the Yuan dynasty's banknote system because of its financial failure.

The yuan Dynasty was undoubtedly the most advanced currency system in the world at that time, and the Yuan Dynasty was also a dynasty with global influence. Therefore, the currency system of the Yuan Dynasty had an important impact on the economic, trade and cultural development of the Eurasian continent as well as on neighboring countries and regions.

Fourth, the export of Chinese currency culture has played an important role in establishing an independent eastern monetary system with Chinese currency as the core. China has unified the currency system since the Qin Dynasty. In the long ancient society, the export of Chinese currency and its monetary culture played a subtle role in the monetary system of neighboring countries. The more prosperous the maritime trade was, the more powerful the Chinese feudal dynasty was. Therefore, the monetary system is relatively stable, the coins are well made and the value of the currency is stable, which is welcomed by all countries in the exchange of commodities. In particular, some countries that do not have their own coins, such as North Korea, Vietnam and Indonesia, take Chinese copper coins as their own currency.

\section{THE CHARACTERISTICS OF CHINESE ANCIENT CURRENCY INTERNATIONALIZATION}

From the perspective of the historical evolution of ancient Chinese currency, there are three characteristics in ancient Chinese currency. First, in the complex and changeable monetary system, copper coin has been playing an important role in the currency circulation for a long time since the Spring and Autumn period and to the late Qing Dynasty, which almost runs through the entire history of ancient Chinese currency. Second, paper money had once been legal tender in currency circulation from Song Dynasty to the middle Yuan 
Dynasty, and was abolished in the middle Ming Dynasty. Third, silver rose gradually in the currency circulation and determined its dominant position in the Ming and Qing Dynasties.

The internationalization of ancient Chinese currency has gone through a long process. In the early Qin Dynasty, Half the money circulated mainly in China, but only a few circulated abroad. However, in the Han Dynasty, especially during the reign of Emperor Han Wu of the Han Dynasty, Wuzhu Coin began to flow into western Regions, East Asia, Korea and Southeast Asia, gradually becoming an important medium of exchange for foreign trade. With the opening of Zhenguan and Kaiyuan in the Tang Dynasty, the scale of Chinese copper coins in overseas circulation expanded. From the Tang, Song, Yuan and Ming Dynasties to the Qianlong Period of the Qing Dynasty, apart from the turbulent times during the dynasty change period, China's comprehensive national strength, economic strength generally accounts for about one third of the world, the Northern Song's economic aggregate once reached $80 \%$ of the world's share! China's ceramics, silk, lacquerware and other dazzling goods and exquisite handicraft products sell well in the international market. On the one hand, China balances the trade balance between China and the rest of the world through its wealth of goods and materials. On the other hand, China possesses a large amount of hard currency, such as gold, silver and copper coins, and its ability to pay is unmatched. As a result, Chinese copper coins and other currencies were almost "universal" and were the leading international currency in the global economic system before modern times. Copper coins of the Song Dynasty, fiat money of the Yuan Dynasty -- paper money and silver of the Ming Dynasty were typical examples.

\section{CONCLUSION}

Throughout the history of currency internationalization in ancient China, the following conclusions can be drawn. First, currency internationalization is a process of gradual growth accompanied by economic strength and comprehensive national strength. Secondly, the larger the economic scale of a country and the stronger the overall national strength of the country, the stronger the currency's competitiveness in the international monetary competition pattern will be, and vice versa. Thirdly, with the higher degree of integration of the world economy, countries with stronger economic selfsufficiency will have stronger monetary independence. The reverse is weaker. Fourth, pure credit money is not reliable, it is difficult for the government to curb the impulse to issue paper money because of the financial crisis, and finally hyperinflation is inevitable. Fifth, China's extensive and profound traditional culture plays an important role in promoting the internationalization of ancient Chinese currency. These provide valuable experience and lessons for the internationalization of $\mathrm{RMB}$ in the face of the challenge of economic antiglobalization.

\section{ACKNOWLEDGMENTS}

I would like to show my deepest gratitude to Professor Yizhong Lei, a respectable, responsible and resourceful scholar, who has provided me with valuable guidance in the writing of this thesis. I' d also like to thank all my friends and colleagues for their encouragement and support.

\section{REFERENCES}

[1] Yizhong Lei. Reviewing the history of China's currency in the surrounding countries cross-border circulation (https://www.zhihu.com/question/50291562)

[2] Baoqing Li, Siyuan Liang. Overseas Outflows of Ancient Chinese Currency and its Implications [J]. Western Finance,2018(11):37-41.

[3] Dongling Weng. Overseas Circulation of Ancient Chinese Currency along the Silk Road and its Enlightenment [J]. Journal of Shihezi University (Philosophy and Social Sciences edition), 2018(6):84-93.

[4] Kaixia Song. A Study on the status of Chinese ancient Currency Culture in the history of world currency $[\mathrm{J}]$. Journal of Linyi Teachers' College, 1992(3):55-57.

[5] Hanhui Guan. A Study on the Circulation of Song and Yuan Banknotes and their Status in the history of world currency: Also on the Differences between The Evolution paths of Chinese and Western currency history [J]. Economic data. 2016 (3) : 32-48.

[6] Yaguang Zhang, Qianqian WANG. Historical Experience of China's Currency Internationalization -- Enlightenment from the Silk Road [J]. Southeast Academic,2017(2):109-118.

[7] The Arab anonymous. China and India [M]. Zhonghua Publishing House, January 2000, pp. $67-$ 78 .

[8] Shouying Zhang. "Chinese Currency History" tells us that the "money shortage" has existed since the Tang Dynasty [R]. China economic review, August 17,2016 (http://www.ceh.com.cn/llpd/2016/08/967886.shtm 1). 